\title{
High-temperature effects on white cement-based slurry infiltrated fiber concrete with metakaolin and fly ash additive
}

\author{
Yurdakul Aygörmez (Main and Corresponding Author) \\ Yildiz Technical University, Department of Civil Engineering Davutpasa Campus \\ 34220, Esenler, Istanbul (Turkey) \\ aygormez@yildiz.edu.tr
}

Mukhallad M. Al-mashhadani

Istanbul Gelisim University, Department of Civil Engineering Avcilar Campus

34310, Avcilar, Istanbul (Turkey)

mashhadani@gelisim.edu.tr

Orhan Canpolat

Yildiz Technical University, Department of Civil Engineering Davutpasa Campus

34220, Esenler, Istanbul (Turkey)

canpolat@yildiz.edu.tr

\author{
Manuscript Code: 14012 \\ Date of Acceptance/Reception: 16.07.2020/22.10.2019 \\ DOI: 10.7764/RDLC.19.2.324
}

\begin{abstract}
In this study, the high flexural parameter properties of Slurry Infiltrated Fiber Concrete (SIFCON) were examined, as was the use of metakaolin and fly ash with PC CEM I 52.5 R (White Cement). 5 series were prepared and metakaolin and fly ash replaced PC CEM I 52.5 R at $25 \%$ and $50 \%$. In this study, while researching White Cement in the production of SIFCON samples, metakaolin which is easy to obtain in kaolin-rich soils, and fly ash, which is a waste material, were also evaluated to reduce $\mathrm{CO} 2$ emission in cement production. $5 \%$ of steel fiber was used in all series and the results of 7 and 28 days flexural and compressive strengths and ultrasonic pulse velocity (UPV) were examined. Given the 28-day test period, a strength increase was observed in metakaolin-added samples, while lower results were obtained in fly ash-added samples since fly ash was not yet completely hydrated. After the 200,400 , and $600{ }^{\circ} \mathrm{C}$ high-temperature tests, the results of flexural and compressive strengths, UPV, and weight loss were examined. The increase in strength after $300^{\circ} \mathrm{C}$ can be caused by drying shrinkage of the matrix, whose C-S-H structure is not yet intact, and compression of the fiber wall. The conversion from $\mathrm{Ca}(\mathrm{OH}) 2$ to $\mathrm{CaO}$ begins at about $400^{\circ} \mathrm{C}$, and the C-S-H structure is quickly destroyed as it approaches $600^{\circ} \mathrm{C}$. $\mathrm{SIFCON}$ samples have the highest mechanical and durability properties by replacing the metakaolin with White Cement by $25 \%$. The lowest results were obtained by replacing the fly ash with White Cement by $50 \%$.
\end{abstract}

Keywords: SIFCON, metakaolin, fly ash, cement replacement, high temperature.

Strength is the most important parameter sought in concrete. High strength concrete is used to provide the desired features. Ductility is another important parameter in concrete after strength. With increased ductility, the problem of brittleness, which is an important disadvantage of concrete, is solved. The use of fiber to prevent brittleness comes into play at the point of looking for a solution to this situation. Using fiber, an enhanced flexural strength and energy absorption capacity for concrete are provided. However, there is a limitation in using fibers; excessive fiber use reduces the workability of concrete (ipek, Yılmaz \& Uysal, 2012).

In the face of this situation, a solution was sought for the fiber usage rate which limits workability. In this case, the idea for contributing concrete to fiber instead of contributing fiber to concrete was formed. In this method, fibers are first placed in the mold and then the slurry is cast into the mold to fill the voids and provide adherence between the fibers. This method is followed by SIFCON (Slurry Infiltrated Fiber Concrete) technology. First, the fiber is placed in the mold between $5-30 \%$ ratios. Then, a slurry consisting of water, sand, cement, pozzolan, and chemical additives is cast into the mold. SIFCON technology was introduced by Lankard at the New Mexico Engineering Research Institute (1984). In manufacturing, after the fiber is placed in the mold at a high rate, the slurry, which involves silica fume, cement, very fine sand, water, and super-plasticizer, is cast into the mold. Vibration is applied to provide diffusion between the fibers and the slurry. SIFCON's uses include pavements, explosive material depots (due to its higher performance against decomposition), plaque production on the elastic ground (for ductility problems), and structures subjected to impact loads (Ipek, \& Aksu, 2019). 
It is necessary to pay attention to two situations during SIFCON production. The first is avoiding inhomogeneous fiber distributions while the other requires paying attention to negative fiber orientation. The fiber density formed inside may be higher than the edges. Additionally, some fibers can be aligned vertically along the outer surface. Attention to these situations during production is important for parameters affecting strength (Giridhar, Rama, \& Rao, 2015). The results obtained by producing SIFCON samples were compared with conventional concrete. Cement, silica fume, fly ash, and slag were used when producing a cement-based slurry. According to the results obtained, SIFCON has been found to have higher results than traditional concrete (Pradeep, \& Sharmila, 2015). In another comparison of SIFCON samples, three different fiber ratios $(6,8.5$, and $11 \%)$ were used. Silica fume and fly ash were also used instead of cement for impact resistance testing of SIFCON samples. Also, different fiber types (micro steel, hook-end, and hybrid) were used. Traditional fiber-reinforced concrete with $2 \%$ hook-end fiber was also prepared as a control mixture. According to the results, SIFCON samples were found to have higher mechanical properties than the control mixture (Ali, 2018). In another study, the mechanical properties of SIFCON samples prepared using the same mixing materials were compared with conventional concrete. While preparing the mixture, $20 \%$ fly ash and $10 \%$ silica fume were used. Comparing conventional mortar and SIFCON samples in terms of compressive, splitting, bending, and impact strengths, SIFCON samples were found to have higher strength. According to this study, SIFCON will be an important alternative for special construction purposes, and traditional fiber reinforced concrete will not work in places where high strength is required (Al-Abdalay, Zeini, \& Kubba, 2019).

This study aimed to use alternative materials instead of cement to reduce $\mathrm{CO}_{2}$ emission in cement production. More environmentally friendly materials were tried obtained by replacing cement with metakaolin, which can be obtained quickly in kaolin-rich soils, and fly ash obtained as a waste product in thermal power plants. In these two substitution states, lower carbon footprint formation is observed (Medjigbodo, Rozière, Charrier, Izoret, \& Loukili, 2018). It is known that the thermal energy spent during the production of metakaolin from kaolin is also less than the thermal energy required for cement production. Since metakaolin contains high levels of $\mathrm{SiO}_{2}$ and $\mathrm{Al}_{2} \mathrm{O}_{3}$, it reacts with $\mathrm{Ca}(\mathrm{OH})_{2}$ formed as a result of cement hydration, forming new calcium silicate hydrate ( $\mathrm{C}-\mathrm{S}-\mathrm{H}$ ) structures and alumina-containing phases $\left(\mathrm{C}_{4} \mathrm{AH}_{13}, \mathrm{C}_{2} \mathrm{ASH}_{8}, \mathrm{C}_{3} \mathrm{AH}_{6}\right)$. With the formation of these products, increases in mechanical and durability properties occur in concrete and mortars (Arslan, Benli, \& Karatas, 2020). In addition to contributing to the formation of C-S-H using fly ash also reduces the cost and permeability. Here the mineralogy of F-class fly ash is directly linked to the composition of the burning coal. Also, the furnace type and combustion process directly affect the properties of fly ash. Fly ash is formed as spherical particles that can form agglomerates; it contains high amounts of CaO (Chousidis, loannou, Rakanta, Koutsodontis, \& Batis, 2016). The pozzolanic properties of fly ash also provide an important advantage. Since they have a larger specific surface area and fineness, they increase the binder volume and create an economic advantage. Studies have shown that using $20 \%$ of both metakaolin and fly ash provides optimum results in terms of cost, environment, and strength (Lv, Huang, Mo, Deng, Qian, \& Wang, 2019). However, the most important disadvantage of the two materials is that it creates a slow pozzolanic reaction and reduces early strength. However, this disadvantage changes over time (Kanchanason, \& Plank, 2018).

Portland Cement was often used in studies with SIFCON. Unlike other studies, White Cement (PC CEM I 52.5 R) was used in the SIFCON production in this study. In addition to using White Cement, metakaolin and fly ash were used as substitutes and the optimum mixture was investigated for cost, environment, and strength. In this way, a different method was followed in producing SIFCON. 5 series were prepared and metakaolin and fly ash were substituted at $25 \%$ and $50 \% .5 \%$ of steel fiber was used in all series, and 7 and 28 days flexural and compressive strengths and UPV results were examined. SIFCON is a material that can be used in different fields, such as military buildings. In these buildings, it is necessary to examine situations after explosion and fire effects. For this purpose, a high-temperature test is required. After 200,400 , and $600^{\circ} \mathrm{C}$ tests, compressive strength, flexural strength, weight loss, and UPV results were investigated.

Methodology

\section{Cement}

PC CEM I 52.5 R type high-performance cement was used in this study. Cement was obtained from Çimsa Cement Industry and Trade Inc. The specific gravity, initial setting time, and final setting time are $3.06 \mathrm{~g} / \mathrm{cm}^{3}, 100$ minutes, and 130 minutes, respectively. The specific surface area (Blaine) is $4600 \mathrm{~cm}^{2} / \mathrm{g}$. The cement's chemical properties are shown in Table 1. Cement was expressed in $\mathrm{C}$ abbreviation. 
Table 1. Oxide composition for cement. Source:Self-Elaboration.

\begin{tabular}{cccccccccccc}
\hline $\begin{array}{c}\text { Chemical } \\
\text { analysis, \% }\end{array}$ & $\mathrm{SiO}_{2}$ & $\mathrm{Al}_{2} \mathrm{O}_{3}$ & $\mathrm{Fe}_{2} \mathrm{O}_{3}$ & $\mathrm{~K}_{2} \mathrm{O}$ & $\mathrm{CaO}$ & $\mathrm{MgO}$ & $\mathrm{K}_{2} \mathrm{O}$ & $\mathrm{Na}_{2} \mathrm{O}$ & $\mathrm{SO}_{3}$ & $\begin{array}{c}\text { Free } \\
\mathrm{CaO}\end{array}$ & L.O.I. \\
\hline $\mathrm{C}$ & 21.60 & 4.05 & 0.26 & 0.35 & 65.7 & 1.30 & 0.35 & 0.30 & 3.30 & 1.60 & 3.20 \\
\hline
\end{tabular}

\section{Metakaolin and fly ash}

The metakaolin used as substitute material in this study was obtained from Kaolin EAD Company while fly ash was obtained from Cates Electrical Production Inc. Metakaolin has high pozzolanic activity and is a fine-grained binder. Its fine-particle properties increase the degree of reaction. Chemical properties of two materials with high pozzolanic activity are indicated in Table 2. Fly ash and metakaolin were expressed in FA and MK abbreviations, respectively.

\begin{tabular}{ccccccccc}
\multicolumn{7}{c}{ Table 2. Oxide composition for metakaolin and fly ash. Source:Self-Elaboration. } \\
\hline $\begin{array}{c}\text { Chemical } \\
\text { analysis, \% }\end{array}$ & $\mathrm{SiO}_{2}$ & $\mathrm{Al}_{2} \mathrm{O}_{3}$ & $\mathrm{Fe}_{2} \mathrm{O}_{3}$ & $\mathrm{CaO}$ & $\mathrm{MgO}$ & $\mathrm{K}_{2} \mathrm{O}$ & $\mathrm{Na}_{2} \mathrm{O}$ & L.O.I. \\
\hline $\mathrm{MK}$ & 56.10 & 40.25 & 0.85 & 0.19 & 0.16 & 0.55 & 0.24 & 1.11 \\
\hline $\mathrm{FA}$ & 54.08 & 26.08 & 6.681 & 2.002 & 2.676 & 4.537 & 0.79 & 1.39 \\
\hline
\end{tabular}

\section{Rilem sand and steel fiber}

The standard sand was obtained from Limak Cement Company. Its unit weight is $1.35 \mathrm{~kg} / \mathrm{m}^{3}$, and the specific weight is $2.56 \mathrm{~g} / \mathrm{cm}^{3}$. Standard sand (Rilem sand) was added as aggregate per BS EN 196-1. The properties of standard sand are shown in Table 3. Hooked end fiber was used in this study and the steel fiber's volume fraction was $5 \%$. The hooked end steel fiber's properties are given in Table 4.

Table 3. Standard limit values and gradation for sand. Source:Self-Elaboration.

\begin{tabular}{ccccccc}
\hline & \multicolumn{7}{c}{ Table 3. Standard limit values and gradation for sand. Source:Self-Elaboration. } \\
\cline { 2 - 7 } Characteristic & 0.08 & 0.16 & 0.5 & 1.0 & 1.6 & 2.0 \\
\hline Remaining (\%) & 99 & 87 & 72 & 34 & 6 & 0 \\
\hline Limit (\%) & $99 \pm 1$ & $87 \pm 5$ & $67 \pm 5$ & $33 \pm 5$ & $7 \pm 5$ & 0 \\
\hline
\end{tabular}

Table 4. The properties of steel fiber.Source:Self-Elaboration.

\begin{tabular}{ccccc}
\hline $\begin{array}{c}\text { Length } \\
(\mathrm{mm})\end{array}$ & $\begin{array}{c}\text { Diameter } \\
(\mu \mathrm{m})\end{array}$ & $\begin{array}{c}\text { Specific } \\
\text { Gravity }\end{array}$ & $\begin{array}{c}\text { Nominal Tensile } \\
\text { Strength }(\mathrm{MPa})\end{array}$ & Aspect Ratio \\
\hline 30 & 0.17 & 7.85 & 2100 & 35.29 \\
\hline
\end{tabular}

\section{Mixture proportions and high-temperature test}

There is no standard in SIFCON mixture design yet. Due to this situation, previous research was used (Krishnan, \& Elavarasi, 2014; Giridhar, Rama, \& Rao, 2015). In most cases, this was also taken into account in this study, and the binder:sand ratio was taken as 1:1. Also, since $5 \%$ to $10 \%$ fiber has been generally used in literature studies, $5 \%$ fiber was used in this study. Metakaolin and fly ash as substitutes were used to investigate the change in the mechanical and durability properties of White Cement-based SIFCON samples with a high rate of metakaolin and fly ash substitution. For this, two different ratios ( $25 \%$ and $50 \%$ ) were used. 5 series were prepared for this study and hooked end steel fiber was used in a $5 \%$ ratio in all mixtures. $100 \%$ PC CEM I $52.5 \mathrm{R}$ was used as the control mixture and $25 \%$ and $50 \%$ metakaolin and fly ash were used in the other mixtures. The 5 series' mixing properties are given in Table 5 . The fibers were placed manually by orienting towards the long edge of the mold. $0-0.125 \mathrm{~mm}$ standard sand was used. $50 \mathrm{~mm}$ cube specimens were used for compressive strength and prismatic specimens were used for flexural strength. First, $5 \%$ of fiber was put into the mold. The binder materials (White Cement, fly ash and metakaolin) were then mixed for 1 minute using a mixer drill. Water was added to the mixture at a binder:water ratio of 1:0.6. After the addition of water, the mixture was stirred for 5 minutes. Standard sand was then added with standard sand:binder ratio of 1:1. The mixture was stirred for a further 5 minutes. The mixture was then placed in the fiber-filled mold. After the vibration was applied, 
the standard cured samples were stored in a humidity chamber at $20 \pm 2^{\circ} \mathrm{C}$ for 24 hours. After one day, the samples were de-molded and stored in the curing pool for 28 days.

\begin{tabular}{cccc} 
& Table 5. Mixture proportions. Source:Self-Elaboration. & \\
\hline Component (\%) & Cement & Metakaolin & $\begin{array}{l}\text { Fly } \\
\text { Ash }\end{array}$ \\
\hline 1 & 100 & 0 & 0 \\
2 & 75 & 0 & 25 \\
3 & 50 & 0 & 50 \\
4 & 75 & 25 & 0 \\
5 & 50 & 50 & 0 \\
\hline
\end{tabular}

After 28 days, the mortar samples were subjected to high-temperature testing. 200,400 , and $600^{\circ} \mathrm{C}$ were used for testing. The samples were first dried for 24 hours at $100^{\circ} \mathrm{C}$. Then, the temperature rise rate of the high-temperature furnace was set as $5^{\circ} \mathrm{C} / \mathrm{min}$. After holding the target temperature for 1 hour, the oven was opened. The samples were let to cool inside the high-temperature furnace to prevent thermal shock. The samples' compressive strength, flexural strength, weight loss, andUPV results after the high-temperature tests were analyzed and checked against the 28-day results.

Results and discussion

\section{Strength results}

The sample after the flexural strength test is shown in Figure 1. The 5 series' flexural and compressive strength results were compared (Figures 2-3). When the results of the mixtures are compared, the addition of metakaolin and fly ash has a negative effect on early compressive strength. The pozzolans react with $\mathrm{Ca}(\mathrm{OH})_{2}$ formed as a result of hydration of the clinker and, therefore, after mixing the water, it has a temporary diluent effect on the Portland cement during the collection of $\mathrm{Ca}(\mathrm{OH})_{2}$. However, over time, the accumulation of $\mathrm{Ca}(\mathrm{OH})_{2}$ in the environment enables the effects of pozzolans to increase the strength of the system. For this reason, a decrease in the early strength is expected with the use of pozzolan, and the strength of later years is expected to reach or even exceed the results of cement mortars (Subaşı, \& Emiroğlu, 2015).

The reason why metakaolin contributes to the compressive and flexural strength of mortars in later years can be explained as follows. When metakaolin is used to partially replace cement, metakaolin contributes to the strength of concrete or mortar due to its different properties. Metakaolin accelerates the cement hydration and pozzolanic reaction and fills the voids due to its fineness (El-Diadamony, Amer, Sokkary, \& El-Hoseny, 2018). Considering the 28-day test period, while the strength increase was observed in metakaolin added samples, lower results were obtained in fly ash added samples compared to the control sample because the fly ash was not yet fully hydrated (Saha, 2018). Since the specific surface and pozzolanic activity index of metakaolin is superior to that of fly ash, the compressive strength results were higher. The pozzolanic materials form additional calcium silicate hydrate (C-S-H) by the reaction of pozzolan reactive silica and calcium hydroxide $(\mathrm{CH})$ formed by cement hydration (Sujjavanich, Suwanvitaya, Chaysuwan, \& Heness, 2017). While the use of pozzolan material at $25 \%$ increased the results, the use of pozzolan material at $50 \%$ started to affect the results negatively (Qasim, Hussein, \& Banyhussan, 2020). This is attributed to the decrease in $\mathrm{CH}$ ratio with an increasing rate. When higher amounts of metakaolin and fly ash are used, they collect around cement particles and interfere with the hydration process (Muduli, \& Mukharjee, 2019). The results of flexural strength were similar to the compressive strength results. Since $5 \%$ of steel fiber was used for SIFCON, flexural strength results were also high (Ipek, \& Aksu, 2019; Sengul, 2018).

When the 7-day compressive strength results were examined, the highest results were obtained in Series 1 with 41.14 $\mathrm{MPa}$. When the 28-day compressive strength results were examined, the highest results were obtained at $57.39 \mathrm{MPa}$ in Series 4 with the hydration of pozzolans. The lowest compressive strength results at the end of 7 and 28 days were obtained as $34.56 \mathrm{MPa}$ and $50.26 \mathrm{MPa}$, respectively, in Series 3. When the 7-day flexural strength results were examined, the highest results were obtained in Series 1 with 33.54 MPa. When the 28-day flexural strength results were examined, the highest results were obtained with $44.53 \mathrm{MPa}$ in Series 4 with the hydration of pozzolans. The lowest flexural strength results at the end of 7 and 28 days were obtained as $27.70 \mathrm{MPa}$ and $39.02 \mathrm{MPa}$, respectively, in Series 
3. For comparison, a normal mortar sample was produced using 28 days with standard PC CEM I 52.5 R cement. The 28 day compressive strength of the mortar was $51.8 \mathrm{MPa}$, while the flexural strength was $10 \mathrm{MPa}$. Higher results were obtained in the SIFCON samples in terms of compressive and flexural strengths compared to the standard mortar sample.
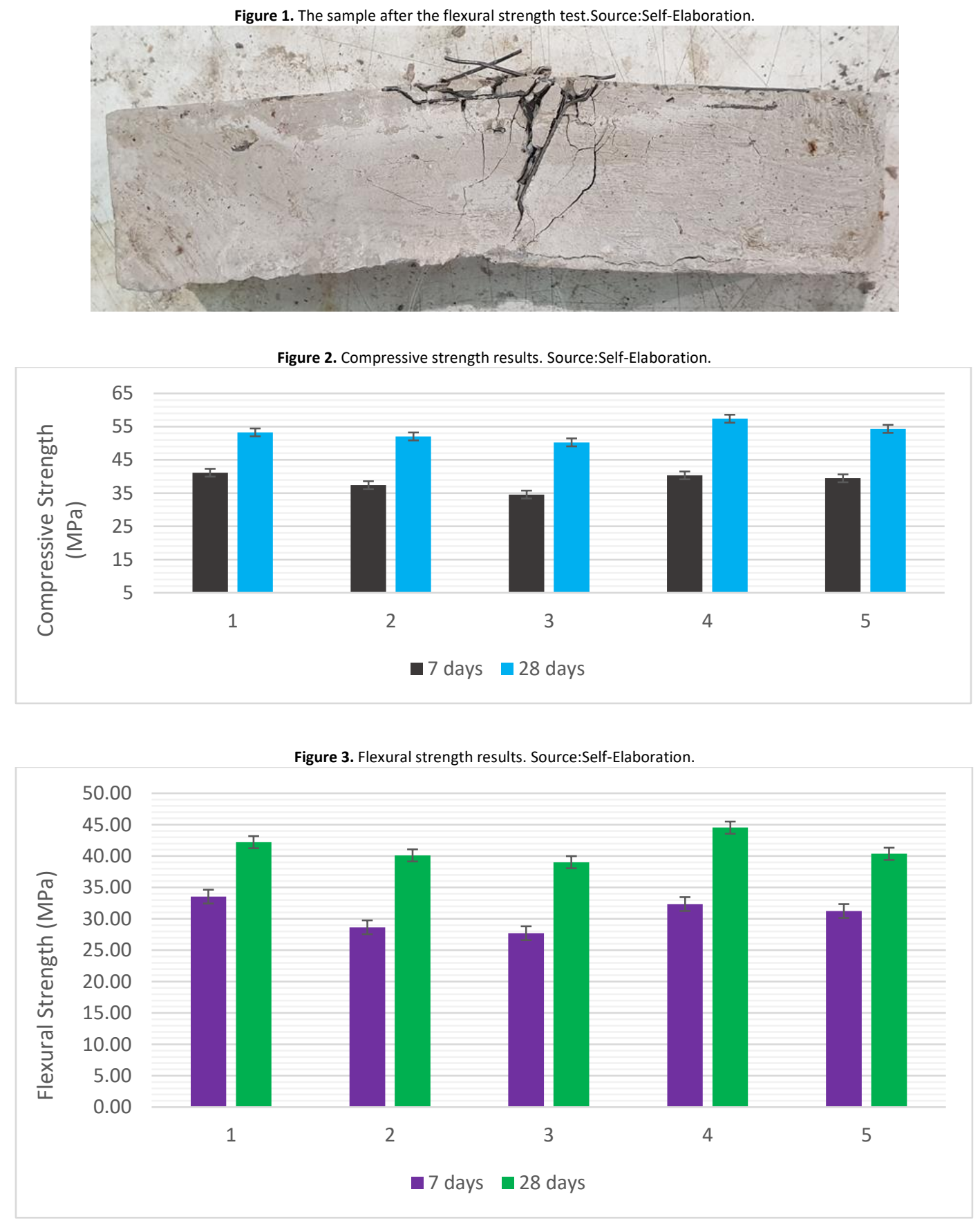

\section{Ultrasonic pulse velocity results}

Using the UPV method, it is possible to examine the homogeneity of the SIFCON material. Thanks to the non-destructive method applied, the evaluation of the structures (continuity of the matrix and the voids structure) is made more easily. At the same time, the accuracy of the compressive strength test was checked using the UPV method. When the UPV results of the five series were examined, the metakaolin additive effect was similar to the compressive strength (Figure 4). Due to its thinness, it fills the voids and increases the UPV results. This is probably due to the thin structure of the kaolin filling the voids in the concrete to form a more gapless concrete. There is also information in the literature about how the fine structure of metakaolin fills the voids. It was reported that MK particles became harder by the fact that they function like physical filling and fill the intermediate spaces in the hardened structure of cement mortar. Additionally, metakaolin has been involved in the pozzolanic reaction to produce additional $\mathrm{C}-\mathrm{S}-\mathrm{H}$, the hydration product, forming contact points between the cement particles that act as binding centers (Saand, Keerio, \& Khan 
Bangwar, 2017; Ashish, 2019). As fly ash was not completely hydrated at 28 days, the results were lower than the control sample (Saha, 2018). When the 28 days UPV results were compared, the highest result was obtained in Series 4 with $4274 \mathrm{~m} / \mathrm{s}$, while the lowest result was found in Series 3 with $4148 \mathrm{~m} / \mathrm{s}$. When the results were examined, it was seen that they were compatible with the studies in the literature (Sampath, \& Asha, 2020; Armagan, \& Canbaz, 2016).

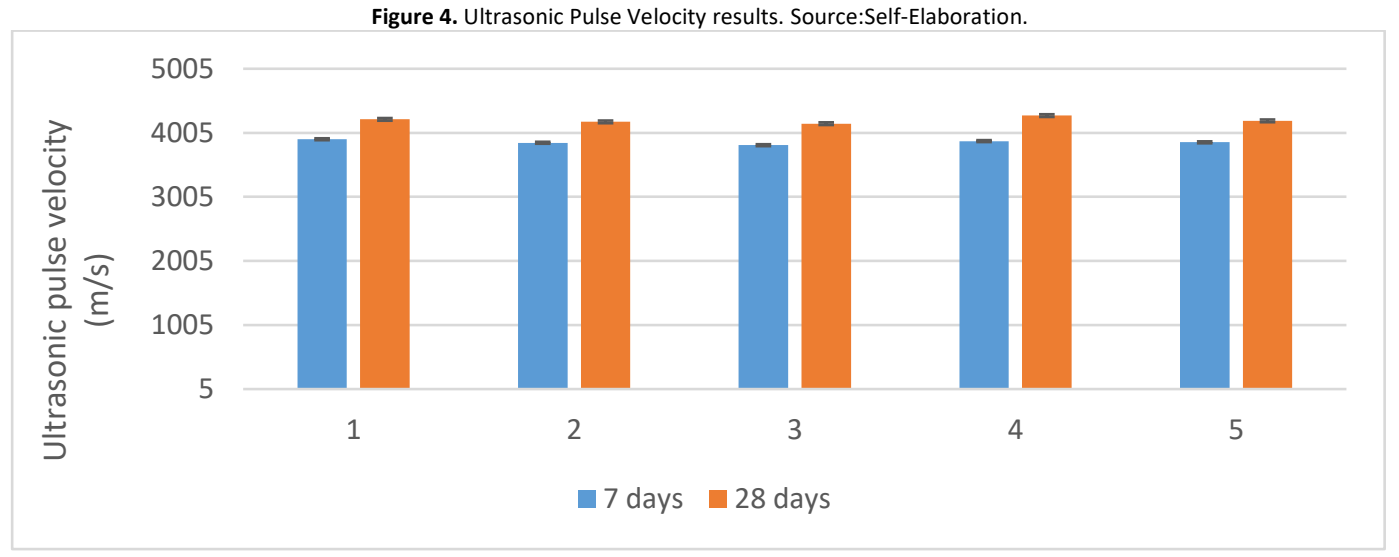

\section{High-temperature test results}

The water in capillary pores escapes at $100^{\circ} \mathrm{C}$. Adsorbed water in gel and structural water in hydrates begins to evaporate towards $300^{\circ} \mathrm{C}$. At this stage, the shrinkage in the concrete is at significant levels and the water trying to get out of the structure creates vapor pressure in the pores. Starting at $300^{\circ} \mathrm{C}$, alumina and iron oxide components begin to dehydrate. The conversion from $\mathrm{Ca}(\mathrm{OH})_{2}$ to $\mathrm{CaO}$ begins around $400^{\circ} \mathrm{C}$ and the $\mathrm{C}-\mathrm{S}-\mathrm{H}$ structure is quickly destroyed as it approaches $600^{\circ} \mathrm{C}$. The increase in sample moisture content under the effect of high temperature increases the vapor pressure. Deterioration in high-strength non-fiber mortars occurred above $300^{\circ} \mathrm{C}$. Fibers in SIFCON samples prevented this condition. The cracks in the distribution similar to the branching of cracks in fiber-free samples were much narrower on the surface of SIFCON samples. An improvement in flexural strength was noted in SIFCON samples at $300^{\circ} \mathrm{C}$ (Beglarigale, Yalçınkaya, Yiğiter, \& Yazıcı, 2016).

The increase in strength after $300^{\circ} \mathrm{C}$ may be due to the drying shrinkage of the matrix, whose $\mathrm{C}-\mathrm{S}$ - $\mathrm{H}$ structure is not yet intact and compressing the fiber wall. Orange (1999) conducted single fiber tensile tests in ultra-high-strength concrete, stated that fiber-matrix adherence was developed by pressure on fiber wall due to matrix shrinkage. Aydın, Yazıcı, and Baradan (2008) showed that the mechanical properties of steel fibrous mortars can develop up to $300^{\circ} \mathrm{C}$. In this study, the damage mechanism was dominant due to the $\mathrm{C}-\mathrm{S}-\mathrm{H}$ structure, which began to deteriorate at $600^{\circ} \mathrm{C}$. Additionally, observational examination of SIFCON samples exposed to $600^{\circ} \mathrm{C}$ showed that the fibers on the surface were darkened and their brittleness increased (Beglarigale, Yalçınkaya, Yiğiter, \& Yazıcı, 2016).

The reason for the strength increase up to $300^{\circ} \mathrm{C}$ can be summarized under three mechanisms as follows. The increase in strength can be achieved by reducing the stresses acting on it due to the drying effect, as well as closer regulation of the capillary pores resulting in greater Van der Waals forces (Aydın, Yazıcı, \& Baradan, 2008). The second mechanism is caused by the non-hydrated cement particles' hydration. Finally, the drying shrinkage of the C-S-H structure leads to compression of the fiber-matrix interface leading to increased strength.

The highest compressive strength at $200^{\circ} \mathrm{C}$ was obtained with $71.19 \mathrm{MPa}$ in Series 4, while the compressive strength results of $59.94 \mathrm{MPa}$ and $48.64 \mathrm{MPa}$ were obtained at 400 and $600^{\circ} \mathrm{C}$, respectively, in Series 4 . The lowest compressive strength at $200^{\circ} \mathrm{C}$ was obtained with $63.12 \mathrm{MPa}$ in Series 3, while the compressive strength results of $54.31 \mathrm{MPa}$ and $42.56 \mathrm{MPa}$ were obtained at 400 and $600^{\circ} \mathrm{C}$, respectively, in Series 3 (Figure 5). The highest flexural strength at $200^{\circ} \mathrm{C}$ was obtained with 55.51 MPa in Series 4, while the flexural strength results of 49.48 MPa and 36.21 MPa were obtained at 400 and $600^{\circ} \mathrm{C}$, respectively, in Series 4 . The lowest flexural strength at $200^{\circ} \mathrm{C}$ was obtained with $48.54 \mathrm{MPa}$ in Series 3 , while the flexural strength results of $43.67 \mathrm{MPa}$ and $28.87 \mathrm{MPa}$ were obtained at 400 and $600{ }^{\circ} \mathrm{C}$, respectively, in Series 3 (Figure 6). 


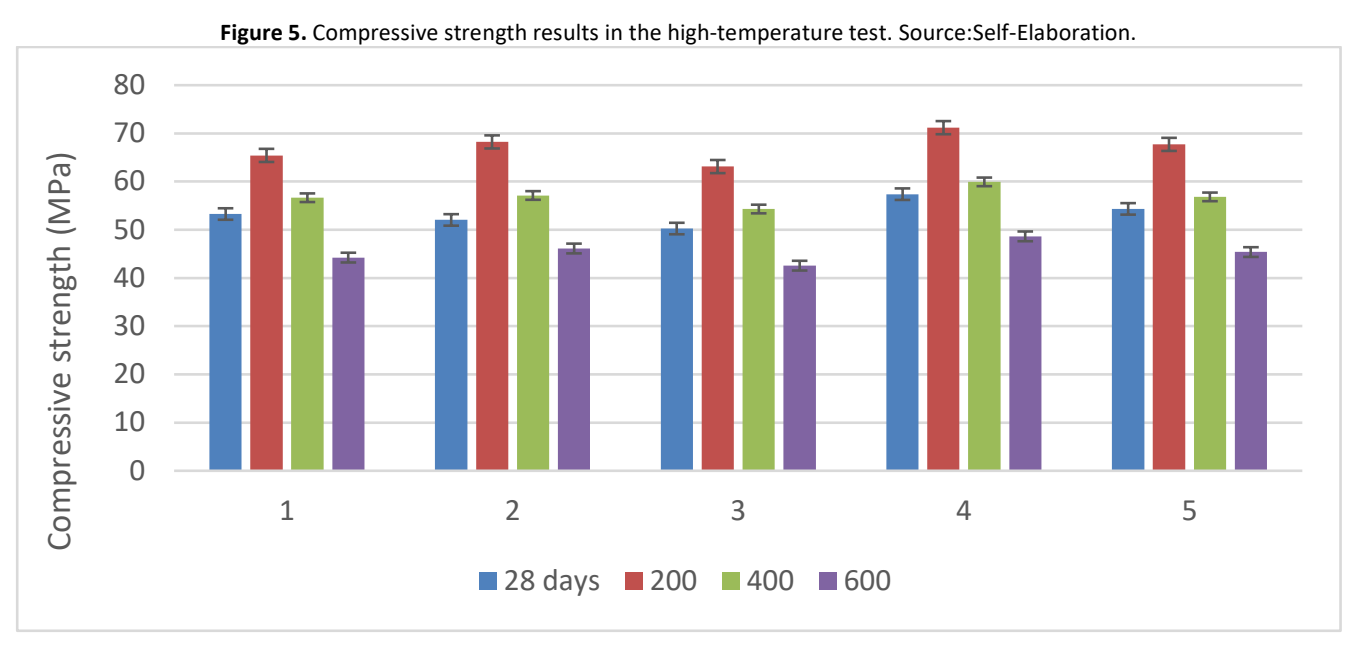

The highest UPV at $200^{\circ} \mathrm{C}$ was obtained with $4339 \mathrm{~m} / \mathrm{s}$ in Series 4, while UPV results of $3821 \mathrm{~m} / \mathrm{s}$ and $3119 \mathrm{~m} / \mathrm{s}$ were obtained at 400 and $600^{\circ} \mathrm{C}$, respectively, in series 4 . The lowest ultrasonic pulse velocity at $200^{\circ} \mathrm{C}$ was obtained with $4187 \mathrm{~m} / \mathrm{s}$ in Series 3, while UPV results of $3656 \mathrm{~m} / \mathrm{s}$ and $2941 \mathrm{~m} / \mathrm{s}$ were obtained at 400 and $600^{\circ} \mathrm{C}$, respectively, in Series 3, (Figure 7). Weight-loss rates were between 1.93 and $2.45 \%$ at $200^{\circ} \mathrm{C}$, between 4.03 and $4.67 \%$ at $400^{\circ} \mathrm{C}$ and between 6.12 and $6.64 \%$ at $600^{\circ} \mathrm{C}$ (Figure 8).

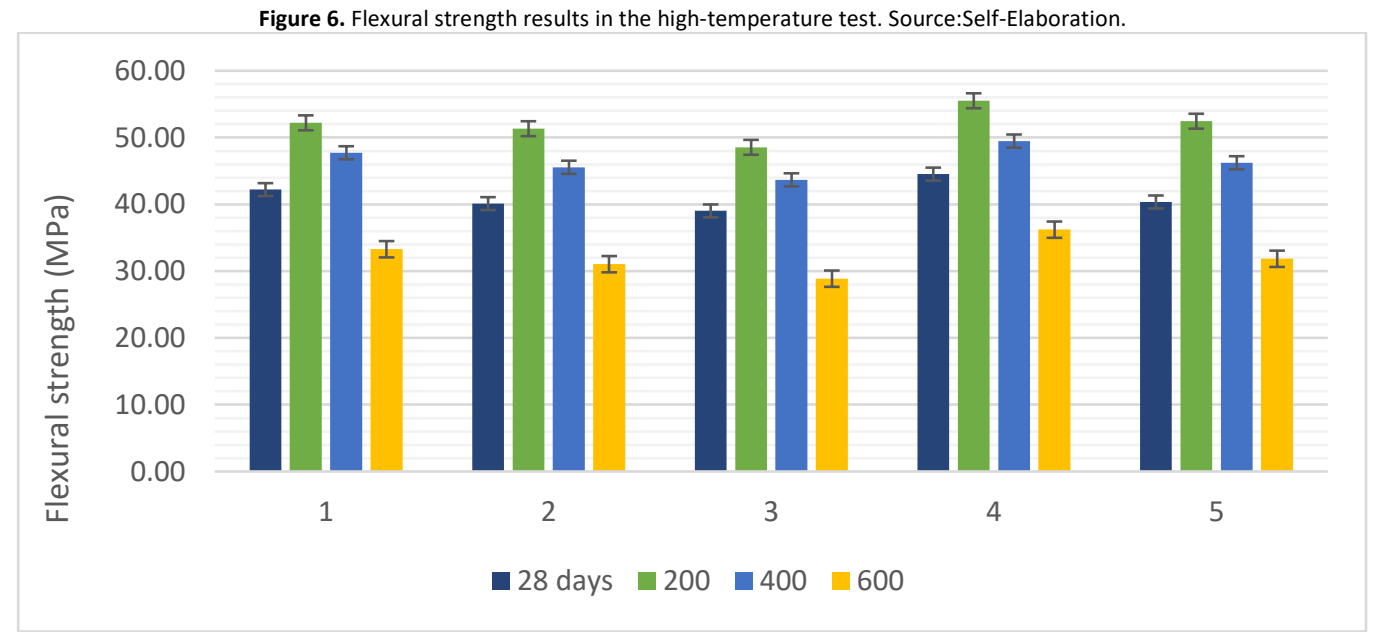

The main components of fly ash and metakaolin binder materials are $\mathrm{Al}_{2} \mathrm{O}_{3}$ and $\mathrm{SiO}_{2}$. Both binder materials have well mechanical and durability properties since they have high impurity rates and a high specific surface area. Compressive strength is importantly reduced after $300^{\circ} \mathrm{C}$ due to free water evaporation and dehydration caused by high temperatures. The solid matrix is severely damaged by the effect of high temperatures, and increased temperatures cause the cracks to widen and matrix pores to form. Thus, with the dehydration reaction, moisture in the matrix moves to the surface of the sample, causing internal damage to the microstructure and, consequently, weight loss. In the heating's early stage, weight loss happens very rapidly due to structural water and free water. Weight loss consists of three water loss forms, adsorbed, free, and chemically bound water. Weight loss exhibits an unexpected increase above $400^{\circ} \mathrm{C}$. The majority of weight loss achieved is between 400 and $600^{\circ} \mathrm{C}$. The major reason for weight loss below $600^{\circ} \mathrm{C}$ is due to the evaporation of free water and condensed hydroxyl groups (Celik, Yilmaz, Canpolat, Al-mashhadani, Aygörmez, \& Uysal, 2018; Akyuncu, Uysal, Tanyildizi, \& Sumer, 2019).

When the temperature rises, the pore structures grow, and water evaporation increases in the matrix. The resulting weight loss leads to the formation of additional voids. Additional voids formed also lead to lower ultrasonic pulse velocity results. All samples showed an important decrease in the UPV values after $300^{\circ} \mathrm{C}$. As a result, damage in the solid matrix after $300^{\circ} \mathrm{C}$ leads to a decrease in the UPV results, which is consistent with the strength results' loss. In addition, high-temperature effects accelerate the formation of microcracks and reduce the density of composites, thus prolonging the propagation time of ultrasonic velocity waves and lower UPV values (Arslan, Uysal, Yılmaz, Almashhadani, Canpolat, Sahin, \& Aygörmez, 2019). 
Figure 7. Ultrasonic pulse velocity results with the high-temperature test. Source:Self-Elaboration.

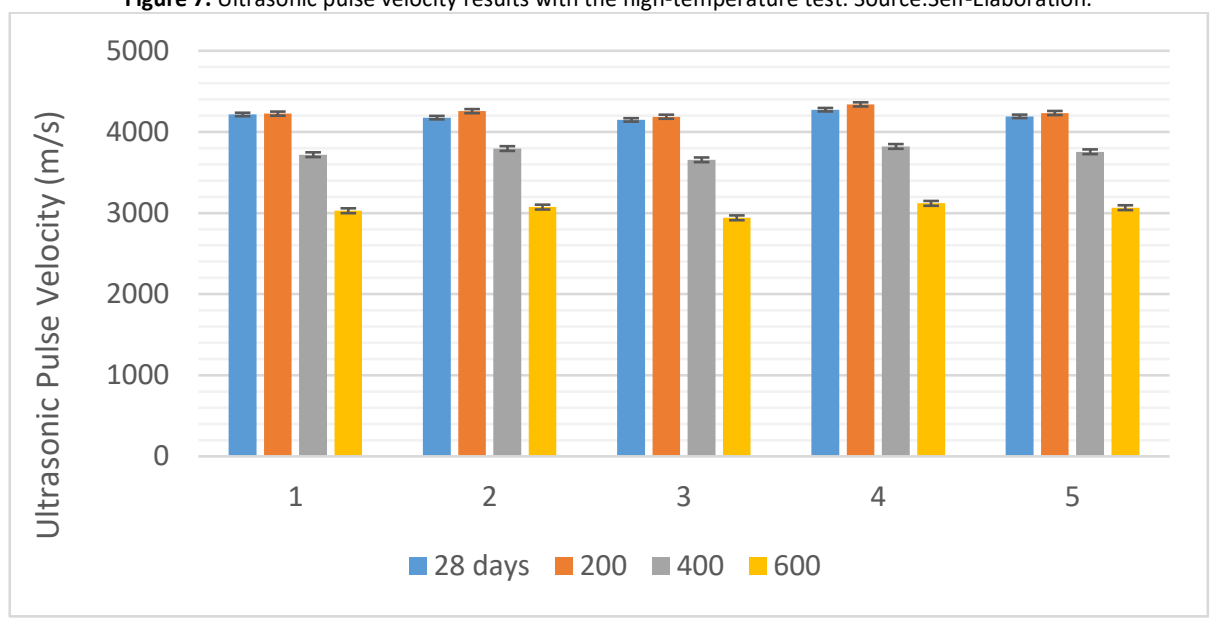

Figure 8. Weight loss results with the high-temperature test. Source:Self-Elaboration.

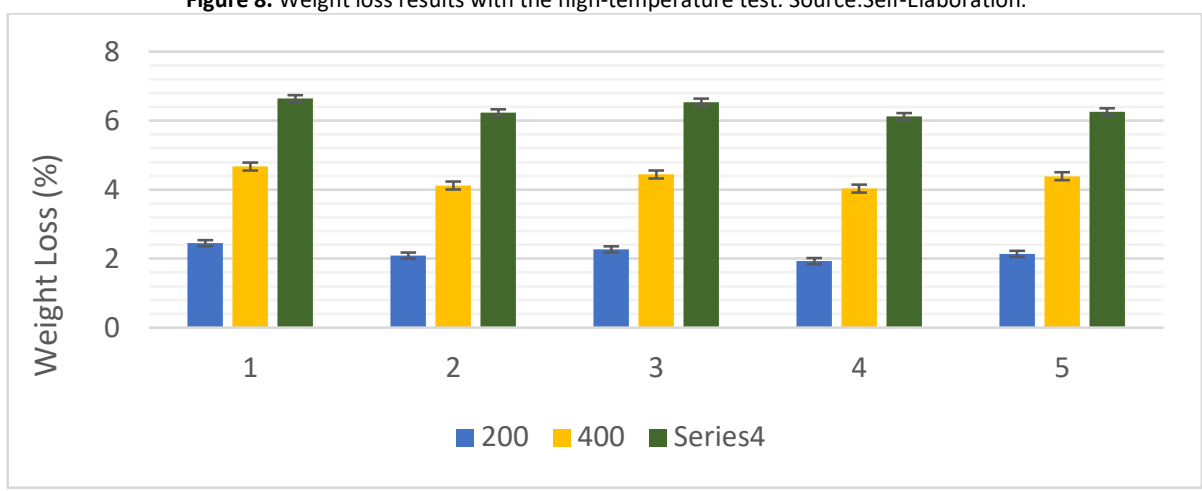

The sample surfaces were examined after the effect of $600^{\circ} \mathrm{C}$ (Figure 9). Photographs were taken shortly after the test. In parallel with the decrease in compressive strength after $600^{\circ} \mathrm{C}$, cracks started to be seen with a color change in the SIFCON samples. However, the cracks observed were limited to the effect of SIFCON. The surface of the samples tended to be coarse compared to the previous situation (Celik, Yilmaz, Canpolat, Al-mashhadani, Aygörmez, \& Uysal, 2018).

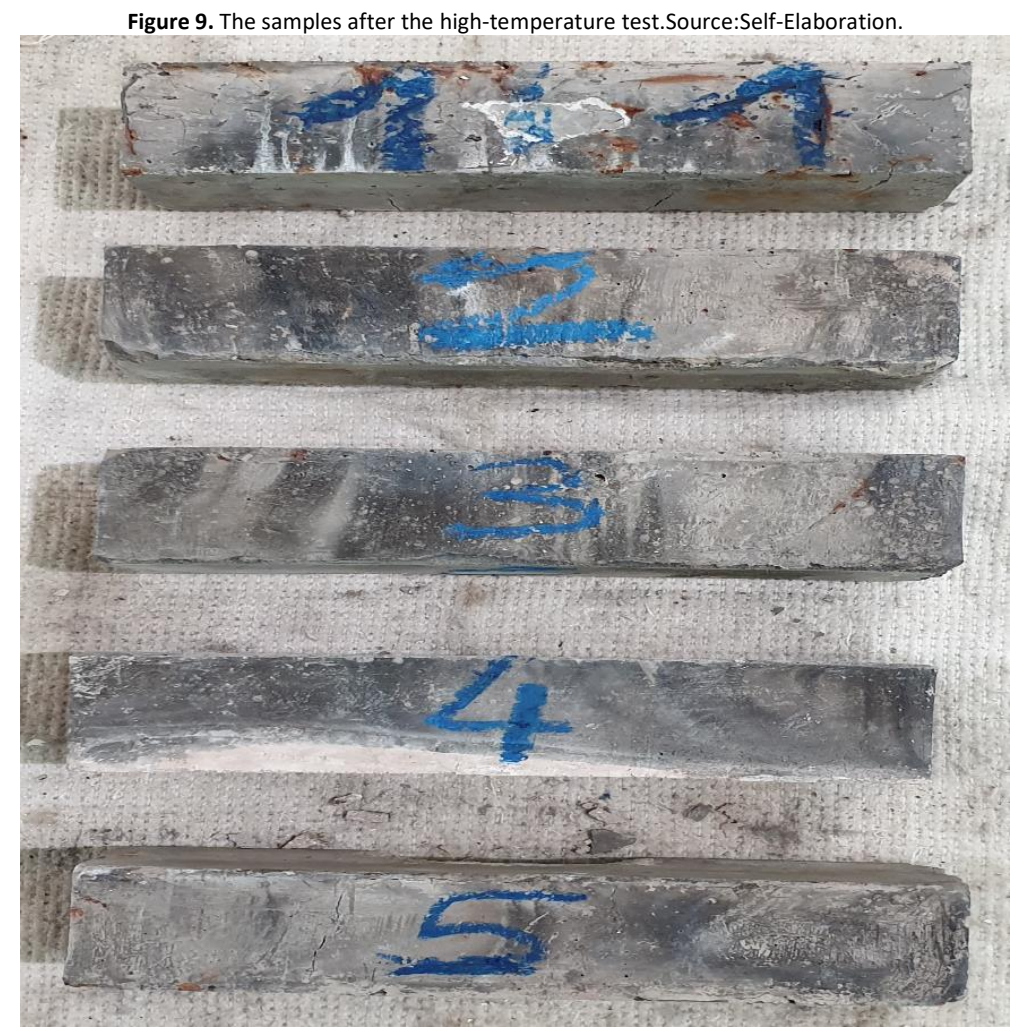


In this study, the samples' mechanical and high-temperature test properties with SIFCON using fly ash, metakaolin, and PC CEM I 52.5 R were analyzed, leading to the following conclusions:

- Considering the 28-day test period, while a strength increase was observed in metakaolin added samples, lower results were obtained in fly ash added samples compared to the control sample because the fly ash was not yet fully hydrated.

- When the 7-day compressive and flexural strength results were examined, the highest results were obtained in Series 1 with $41.14 \mathrm{MPa}$ and $33.54 \mathrm{MPa}$, respectively. When the 28-day compressive and flexural strength results were examined, the highest results were obtained with $57.39 \mathrm{MPa}$ and $44.53 \mathrm{MPa}$ in Series 4 with the hydration of pozzolans.

- Metakaolin was involved in the pozzolanic reaction to produce additional C-S-H, forming contact points between the cement particles. As fly ash was not completely hydrated at 28 days, the ultrasonic pulse velocity results were lower than the control sample.

- The increase in strength after $300^{\circ} \mathrm{C}$ may be due to the drying shrinkage of the matrix, whose C-S-H structure is not yet intact, and compressing the fiber wall. The conversion from $\mathrm{Ca}(\mathrm{OH})_{2}$ to $\mathrm{CaO}$ begins around $400^{\circ} \mathrm{C}$ and the $\mathrm{C}-\mathrm{S}-\mathrm{H}$ structure is quickly destroyed as it approaches $600^{\circ} \mathrm{C}$. The cracks in the distribution similar to the branching of cracks in fiber-free samples were much narrower on the surface of SIFCON samples.

- The highest compressive strength at $200^{\circ} \mathrm{C}$ was obtained with $71.19 \mathrm{MPa}$ in Series 4 , while the compressive strength results of $59.94 \mathrm{MPa}$ and $48.64 \mathrm{MPa}$ were obtained at 400 and $600^{\circ} \mathrm{C}$, respectively, in Series 4 .

- Weight loss consists of three water loss forms, adsorbed, free, and chemically bound water. Weight loss exhibits an unexpected increase above $400^{\circ} \mathrm{C}$. Weight-loss rates were between 1.93 and $2.45 \%$ at $200^{\circ} \mathrm{C}$, between 4.03 and $4.67 \%$ at $400^{\circ} \mathrm{C}$ and between 6.12 and $6.64 \%$ at $600^{\circ} \mathrm{C}$.

- If an analysis is made of all series, the best results were obtained in the case of replacing the White Cement with $25 \%$ metakaolin under both durability and normal conditions. The lowest results were obtained by replacing the White Cement with $50 \%$ fly ash.

Akyuncu, V., Uysal, M., Tanyildizi, H., \& Sumer, M. (2019). Modeling the weight and length changes of the concrete exposed to sulfate using artificial neural network. Journal of Construction, 17(3), 337-353.

Al-Abdalay, N. M., Zeini, H. A., \& Kubba, H. Z. (2019). Effect of Impact Load on SIFCON. Global Journal of Research in Engineering.

Ali, M. A. (2018). Properties of slurry infiltrated fiber concrete (SIFCON). PhD diss., Ph. D Thesis, civil engineering dep., UOT, Iraq.

Armagan, K., \& Canbaz, M. (2016). Effect of fiber type on freeze thaw durability of SIFCON International. Journal of Advances in Mechanical and Civil Engineering, 3(5), 56-59.

Arslan, A. A., Uysal, M., Yılmaz, A., Al-mashhadani, M. M., Canpolat, O., Şahin, F., \& Aygörmez, Y. (2019). Influence of wetting-drying curing system on the performance of fiber reinforced metakaolin-based geopolymer composites. Construction and Building Materials, 225, 909-926.

Arslan, F., Benli, A., \& Karatas, M. (2020). Effect of high temperature on the performance of self-compacting mortars produced with calcined kaolin and metakaolin. Construction and Building Materials, 256, 119497.

Ashish, D. K. (2019). Concrete made with waste marble powder and supplementary cementitious material for sustainable development. Journal of cleaner production, $211,716-729$.

Aydın, S., YazıII, H., \& Baradan, B. (2008). High temperature resistance of normal strength and autoclaved high strength mortars incorporated polypropylene and steel fibers. Construction and Building Materials, 22(4), 504-512.

Beglarigale, A., Yalçınkaya, Ç., Yiğiter, H., \& Yazıcı, H. (2016). Flexural performance of SIFCON composites subjected to high temperature. Construction and Building Materials, 104, 99-108.

Chousidis, N., loannou, I., Rakanta, E., Koutsodontis, C., \& Batis, G. (2016). Effect of fly ash chemical composition on the reinforcement corrosion, thermal diffusion and strength of blended cement concretes. Construction and Building Materials, 126, 86-97.

Celik, A., Yilmaz, K., Canpolat, O., Al-Mashhadani, M. M., Aygörmez, Y., \& Uysal, M. (2018). High-temperature behavior and mechanical characteristics of boron waste additive metakaolin based geopolymer composites reinforced with synthetic fibers. Construction and Building Materials, 187, 1190-1203.

El-Diadamony, H., Amer, A. A., Sokkary, T. M., \& El-Hoseny, S. (2018). Hydration and characteristics of metakaolin pozzolanic cement pastes. HBRC journal, 14(2), 150-158. 
Giridhar, R., Rama, P., \& Rao, M. (2015). Determination of mechanical properties of slurry infiltrated concrete (SIFCON). International Journal for Technological Research in Engineering, 2(7), 1366-1368.

Ipek, M., Yilmaz, K., \& Uysal, M. (2012). The effect of pre-setting pressure applied flexural strength and fracture toughness of reactive powder concrete during the setting phase. Construction and Building Materials, 26(1), 459-465.

Ipek, M., \& Aksu, M. (2019). The effect of different types of fiber on flexure strength and fracture toughness in SIFCON. Construction and Building Materials, 214, 207-218.

Kanchanason, V., \& Plank, J. (2018). Effectiveness of a calcium silicate hydrate-Polycarboxylate ether (CSH-PCE) nanocomposite on early strength development of fly ash cement. Construction and Building Materials, 169, 20-27.

Krishnan, M. G., \& Elavarasi, D. (2014). Experimental study on slurry infiltrated fibrous concrete with sand replaced by Msand. International Journal of Engineering Research \& Technology, 3, 534-537.

Lankard, D. R. (1984). Slurry infiltrated fiber concrete (SIFCON): Properties and applications. MRS Online Proceedings Library Archive, 42.

Lv, L., Huang, P., Mo, L., Deng, M., Qian, J., \& Wang, A. (2019). Properties of magnesium potassium phosphate cement pastes exposed to water curing: A comparison study on the influences of fly ash and metakaolin. Construction and Building Materials, 203, 589-600.

Medjigbodo, G., Rozière, E., Charrier, K., Izoret, L., \& Loukili, A. (2018). Hydration, shrinkage, and durability of ternary binders containing Portland cement, limestone filler and metakaolin. Construction and Building Materials, 183, 114-126.

Muduli, R., \& Mukharjee, B. B. (2019). Effect of incorporation of metakaolin and recycled coarse aggregate on properties of concrete. Journal of cleaner production, 209, 398-414.

Orange, G. (1999). A New Generation of UHP Concrete (DUCTAL), Damage Resistance and Micromechanical Analysis. In Proceedings of the Third International RILEM Workshop on HPFRCC (pp. 101-111). RILEM Publications SARL.

Pradeep, T., \& Sharmila, S. (2015). Cyclic behavior of RC beams using SIFCON sections. International Journal of Innovative Research in Science, Engineering and Technology, 4(9).

Qasim, G. J., Hussein, Z. M., \& Banyhussan, Q. S. (2020). Evaluating the mechanical performance of hot asphalt mixtures modified with metakaolin as filler. Periodicals of Engineering and Natural Sciences, 8(1), 113-124.

Saand, A., Keerio, M. A., \&Khan Bangwar, D. (2017). Effect of metakaolin developed from local natural material soorh on workability, compressive strength, ultrasonic pulse velocity and drying shrinkage of concrete. Architecture Civil Engineering Environment, 10(2).

Saha, A. K. (2018). Effect of class F fly ash on the durability properties of concrete. Sustainable environment research, 28(1), 25-31.

Sampath, P., \& Asha, P. (2020). Mechanical properties of slurry infilterated fibrous concrete (Material) with hooked end fibre. Materials Today: Proceedings.

Sengul, O. (2018). Mechanical properties of slurry infiltrated fiber concrete produced with waste steel fibers. Construction and Building Materials, 186, 1082-1091.

Subaşı, A., \& Emiroğlu, M. (2015). Effect of metakaolin substitution on physical, mechanical and hydration process of White Portland cement. Construction and Building Materials, 95, 257-268.

Sujjavanich, S., Suwanvitaya, P., Chaysuwan, D., \& Heness, G. (2017). Synergistic effect of metakaolin and fly ash on properties of concrete. Construction and Building Materials, 155, 830-837. 